\title{
PENERAPAN MODEL PEMBELAJARAN NoS UNTUK MENINGKATKAN PEMAHAMAN NoS SISWA SEKOLAH DASAR
}

\author{
Suratmi $^{1^{*}}$, Ari Widodo ${ }^{2}$ \\ ${ }^{1}$ Universitas Pendidkan Indonesa \\ ${ }^{1}$ Universitas Sriwijaya \\ ${ }^{2}$ Universitas Pendidikan Indonesia Bandung \\ ${ }^{1}$ suratmi@upi.edu
}

\begin{abstract}
An understanding of the Nature of science (NoS) is very important for students because it relates to students' understanding of how a scientist works, scientific literacy and being able to recognize pseudoscience concepts. This study aims to determine differences understanding of Nature of science (NoS) elementary school students before and after using the Nature of science (NoS) learning model. The method used is a pre-experiment with one group pretest postest design. The instrument used was the NoS understanding questionnaire and observation sheet. The collected data was analyzed by quantitative descriptive. The results of this study indicate students' initial understanding of NoS with a percentage of $84 \%$ in the good category and after learning with the NoS model with a percentage of $89 \%$ in the very good category. Seen from the lowest aspect of Nos is students' understanding of law and theory. After t-test, it can be concluded that there are differences in students' understanding of NoS before and after using NoS learning.
\end{abstract}

Keywords: elementary school; NoS learning; NoS understanding

\begin{abstract}
Abstrak
Pemahaman tentang Nature of science (NoS) sangat penting bagi peserta didik karena berkaitan dengan pemahaman peserta didik bagaimana seorang ilmuwan bekerja, literasi sains dan mampu mengenali konsep pseudosains yang ditemui dalam kehidupan sehari-hari. Penelitian ini bertujuan untuk mengetahui perbedaan pemahaman NoS peserta didik sekolah dasar sebelum dan sesudah menggunakan model pembelajaran Nos (Nature of science). Metode yang digunakan adalah preekperimen dengan desain one grup pretest postest. Instrumen yang digunakan adalah angket pemahaman NoS dan lembar observasi. Data yang terkumpul dianalisis secara deskriftif kuantitatif. Hasil penelitian ini menunjukkan pemahaman awal peserta didik terhadap NoS dengan persentase $84 \%$ dan setelah pembelajaran dengan model NoS dengan persentase $89 \%$. Dilihat dari aspek Nos yang paling rendah adalah pemahaman peserta didik tentang hukum dan teori. Setelah dilakukan uji t dapat disimpulkan bahwa adanya perbedaan pemahaman NoS peserta didik sebelum dengan sesudah menggunakan pembelajaran NoS.
\end{abstract}

Kata Kunci: pemahaman NoS; pembelajaran NoS; sekolah dasar

\begin{tabular}{llll}
\hline Received & $: 2021-05-31$ & Approved & $: 2021-07-31$ \\
Reviesed & $: 2021-07-30$ & Published & $: 2021-07-31$ \\
\hline
\end{tabular}

(i) (?) Jurnal Cakrawala Pendas is licensed under a Creative Commons AttributionShareAlike 4.0 International License.

\section{Pendahuluan}

Pemahaman tentang Nature of science (NoS) sangat penting bagi peserta didik. Pemahaman tentang Nos dapat dikembangkan melalui pembelajaran tentang NoS. Pembelajaran mengenai NoS, peserta didik akan memiliki latar belakang yang penting, merinci bagaimana sains dan ilmuwan bekerja dan bagaimana pengetahuan ilmiah tercipta, divalidasi, dan dipengaruhi (Mccomas, 2015) memiliki pandangan yang akurat tentang apa itu sains, termasuk jenis-jenis pertanyaan yang dapat dijawab oleh sains, bagaimana sains berbeda dengan disiplin ilmu 
lainnya, kekuatan dan keterbatasan pengetahuan ilmiah (Bell, 2008); NoS sebagai standar kelulusan dari pendidikan sains sebelum memasuki perkuliahan sehingga memiliki literasi sains (Wallace, 2013); dapat mengenali dan menolak klaim pseudosains saat ditemui dalam kehidupan sehari-hari (Khine, 2013); serta sebagai cara untuk mengetahui serta karakteristik pengembangan pengetahuan ilmiah (Mercado et al., 2015); dapat meningkatkan literasi sains (Holbrook \& Rannikmae, 2009). Berdasarkan beberapa pendapat ini, maka pemahaman mengenai NoS berdampak pada kemampuan bekerja dengan sains dan menggunakannya dalam kehidupan sehari-hari. Oleh karena itu, guru dituntut untuk membelajarkan Nature of science (NoS) di sekolah.

Lederman et al., (2002) menyebutkan bahwa hampir semua ilmuwan, pendidik sains, dan organisasi pendidikan sains telah sepakat untuk membantu peserta didik mengembangkan konsepsi pengetahuan tentang NoS. Temuan Olson (1998) menunjukkan bahwa ide NoS jarang menjadi harapan peserta didik dalam pembelajaran, ide NoS hanya terdapat dalam bahan ajar tambahan, kurikulum yang diterbitkan kurangnya memunculkan ide NoS secara konsisten, dan hampir semua dokumen yang dianalisis tentang standar NoS tidak memberikan dukungan konseptual atau pedagogis yang memadai agar NoS ditafsirkan secara akurat atau diterjemahkan ke dalam makna pengalaman bagi peserta didik. Jumanto \& Widodo, (2018) juga menemukan bahwa sebagian guru masih merasa asing dengan istilah NoS. Faktor lain adalah karena keengganan guru untuk memasukkan aspek NoS dalam pengajaran mereka.

Hasil penelitian Lederman et al., (2002) secara konsisten menunjukkan bahwa peserta didik TK sampai kelas 12 dan juga guru, belum mencapai pemahaman yang diinginkan tentang NoS (hakikat sains). Hasil ini dikuat oleh Bell (2008), hasil penelitian menunjukkan bahwa guru dan peserta didik tidak memiliki pemahaman yang sesuai tentang Nos. Salah satu permasalahannya dimungkinkan karena hampir semua buku teks sains berfokus pada pengetahuan sains, sementara penyelidikan ilmiah, pemikiran ilmiah dan aspek sosial sains sering diabaikan (Jiang \& Mccomas, 2014). Berdasarkan hal tersebut, maka akan berdampak negatif pada pemahaman guru, pembelajaran di dalam kelas, dan terakhir pemahaman peserta didik tentang sains.

Penelitian mengenai Nos di Indonesia mulai berkembang, informasi pemahaman Nos peserta didik sekolah dasar, guru sekolah dasar dan calon guru sekolah dasar sudah diteliti. Hasil penelitian Pemahaman NoS peserta didik dan guru sekolah dasar masih dalam kategori cukup (Adi \& Widodo, 2018; Jumanto \& Widodo, 2018). Sementara itu pemahaman calon guru dan guru sekolah dasar mengenai Nos sudah baik (Rahayu \& Widodo, 2019; Tursinawati \& Widodo, 2019). Namun untuk pembelajaran dengan model Nos sendiri belum dilakukan.

Selama ini Nos diajarkan di sekolah masih dalam bentuk pendekatan implisit. Hasil penelitian Adi dan Widodo (2018) menyampaikan bahwa di Thailand, guru sains mengajar NoS secara implisit, di mana mereka tidak berencana untuk mengajar NoS, untuk membuat peserta didik sadar akan NoS, dan untuk memperoleh ide-ide peserta didik tentang NoS. Pendekatan implisit menyarankan bahwa dengan "melakukan sains" siswa juga akan memahami NOS (Lawson, 1982). Sebagian besar kurikulum tahun 60-an dan 70-an mengadopsi pendekatan ini dan menekankan langsung, kegiatan berbasis penyelidikan dan/atau instruksi keterampilan proses. Studi penelitian telah menunjukkan bahwa pendekatan implisit bukan cara yang efektif untuk meningkatkan pemahaman NOS peserta didik. Untuk itu, NoS perlu diajarkan secara eksplisit dalam pembelajaran di sekolah dasar.

Pendekatan ekplisit dalam penelitian ini adalah melakukan tahapan pembelajaran dengan menekankan aspek Nos yang akan diajarkan kepada peserta didik. Dalam penyusunan desain pembelajaran, peneliti dengan berkolaborasi membuat desain pembelajaran Nos dengan 
memuat aspek-aspek NoS yang akan diajarkan. Desain pembelajaran Nos yang dikembangkan dapat dilihat pada gambar berikut ini:

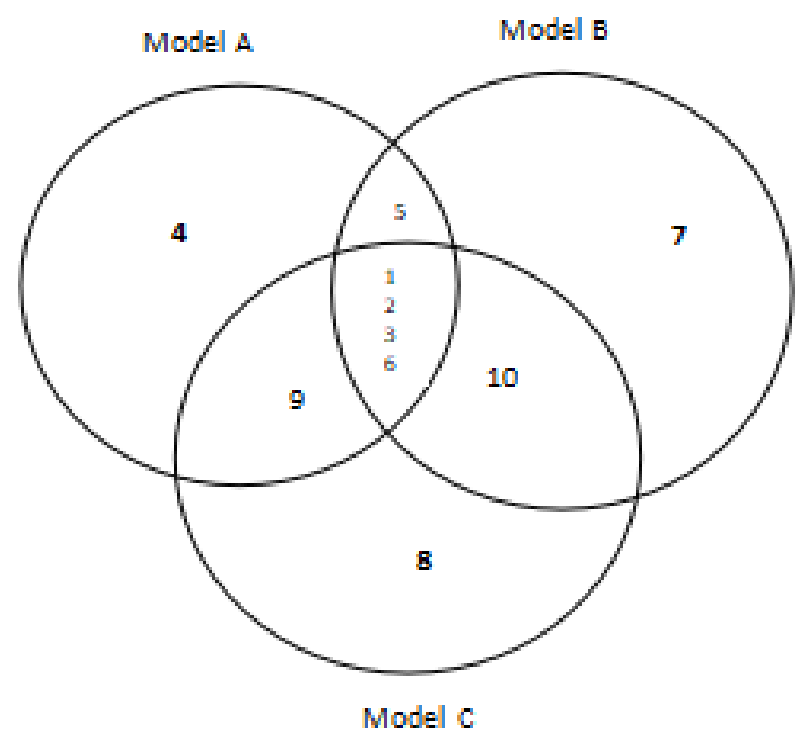

Keterangan:

1. Kreatif

2. Tentatif

3. Subjektif

4. Kedekatan sosial budaya

5. Hukum dan teori

6. Empirik

7. Metode Ilmiah

8. Tidak dapat menjawab semua pertanyaan

9. Komunikasi dan kolaborasi

10.Etos ilmiah

Gambar 1. Desain Model Pembelajaran Nos

Penjelasan aspek-aspek Nos dalam pembelajaran ini adalah sebagai berikut: 1) Kreativitas, pengetahuan ilmiah tercipta dari imajinasi, kreativitas, dan penalaran logis manusia yang terus berkembang dan didasarkan pada perencanaan, pengamatan dan kesimpulan; 2) Tentatif, pengetahuan ilmiah memiliki keterbatasan, bersifat tahan lama tetapi dapat berubah dengan adanya bukti atau ide yang baru yang lebih kuat; 3) Subjektif, pengetahuan dipengaruhi oleh subjektivitas pribadi yang meliputi nilai,kepercayaan, agenda diri dan pengalaman; 4) Kedekatan dengan social dan budaya, pengetahuan ilmiah dipengaruhi dan dapat mempengaruhi kehidupan masyarakat (social, ekonomi, etis, budaya dan teknologi); 5) Terdapat perbedaan antara hukum dan teori ilmiah, pengetahuan ilmiah terdiri dari teori yaitu penjelasan yang telah dibuktikan dan hukum adalah deskripsi antara hubungan; 6) Empiris, pengetahuan ilmiah berbasis empiris yang di dalamnya melibatkan penyelidikan, bukti observasi, pengukuran; 7) Tidak ada tahapan ilmiah yang universal, dalam ilmu pengetahuan ilmuwan menggunakan berbagai metode dan alat dalam merumuskan hipotesis, teori, dan model; 8) Kerjasama dan kolaborasi, sertifikasi, and disseminasi; pengetahuan ilmiah dikembangkan dari proses kerjasama, kolaborasi dan aktivitas professional antara multidisiplin ilmu, budaya dan bangsa; 9) sains tidka bisa menjawab semua pertanyaan; 10) Etos ilmiah, pengetahuan ilmiah dibangun atas dasar etos kerja ilmuwan yang memiliki kejujuran 
intelektual, sikap saling menghargai terhadap subjek penelitian dan lingkungan, kebebasan dan keterbukaan.

Adapun aspek NoS yang dikembangkan adalah Model B yang terdiri dari aspek kreatif, tentatif, subjektif, empirik, hukum dan teori, metode ilmiah, dan etos ilmiah. Desain model pembelajaran NoS dikembangkan dengan membuat struktur dalam dan struktur luar dalam diri peserta didik dan struktur dalam dan luar dalam diri guru. Struktur dalam dan struktur luar dituangkan dalam bentuk sintaks pembelajaran yang dapat diterapkan dalam pemebeljaran di sekolah dasar. Untuk itu dilakukan penelitian ini dengan tujuan untuk mengetahui perbedaan pemahaman Nos peserta didik sekolah dasar sebelum dan setelah menggunakan model pembelajaran Nos.

\section{Metode Penelitian}

Penelitian ini merupakan penelitian Pre-eksperimen dengan desain one group pretest postest. Desain penelitian ini bertujuan untuk melihat perbedaan pemahaman peserta didik sebelum dan sesudah diberi perlakukan (Fraenkel \& Wallen, 1993). Desain penelitian dapat dilihat pada tabel 1.

Tabel 1. Desain Penelitian one group pretest postest.

\begin{tabular}{lll}
\hline $\mathrm{O}_{1}$ & $\mathrm{X}$ & $\mathrm{O}_{2}$ \\
\hline
\end{tabular}

Keterangan:

$\mathrm{O}_{1} \quad$ : Tes awal

$\mathrm{O}_{2} \quad$ : Tes Akhir

$\mathrm{X} \quad$ : Model Pembelajaran NoS

Berdasarkan desain pembelajaran pada tabel 1 sebelum pembelajaran dilakukan tes awal untuk mengetahui pemahaman peserta didik sebelum menerapkan model pembelajaran NoS dan dilakukan tes akhir sesudah menerapkan model pembelajaran NoS. Model Pembelajaran Nos diterapkan dengan mengacu kepada sintak pembelajaran Nos yang telah dikembangkan 5 langkah pembelajaran yaitu 1) Mengaktifkan pengetahuan sebelumnya tentang bagaimana ilmuwan menggunakan metode ilmiah dalam melakukan penelitian dan mengembangkan ilmu pengetahuan, 2) Menemukan bukti secara ilmiah bahwa dalam melakukan metode ilmiah, ilmuwan harus kreatif, tentatif, empirik, hukum dan teori dan etos ilmiah, 3) Menganalisis bukti bahwa dalam bekerja dan mengembangkan pengetahuan, ilmuwan sudah sesuai dengan metode ilmiah yang dipengaruhi kreatif, tentatif, empirik, hukum dan teori dan etos ilmiah, 4) Mengkomunikasikan hasil kajiannya bahwa dalam bekerja dan mengembangkan pengetahuan, ilmuwan sudah sesuai dengan metode ilmiah yang dipengaruhi kreatif, tentatif, empirik, hukum dan teori dan etos ilmiah, 5) Menyimpulkan bahwa dalam bekerja dan mengembangkan pengetahuan, ilmuwan sudah sesuai dengan metode ilmiah yang dipengaruhi kreatif, tentatif, empirik, hukum dan teori dan etos ilmiah.

Penelitian ini dilakukan di salah satu Sekolah dasar di Kota Bandung. Penelitian dilakukan pada semester ganjil 2019/2020 dengan subjek penelitian peserta didik kelas V yang berjumlah 22 orang. Instrumen penelitian yang digunakan adalah angket pemahaman NoS dan lembar observasi pembelajaran. Angket pemahaman NoS yang berjumlah 21 pernyataaan yang dikembangkan dengan skala Linkert dengan jawaban sangat setuju, setuju, netral, tidak setuju dan sangat tidak setuju. Angket pemahaman NoS diadaptasi dari angket yang dikembangkan 
oleh Rahayu \& Widodo (2019). Angket pemahaman Nos yang digunakan dalam penelitian ini dikembangkan sesuai dengan aspek NoS yang diajarkan dalam pembelajaran meliputi aspek NoS yaitu kreatif, tentatif, subjektif, empirik, hukum dan teori, metode ilmiah, dan etos ilmiah.

Data yang sudah terkumpul dilakukan analisi secara deskriptif kuantitatif. Data yang dideskripsikan adalah pemahaman peserta didik tentang NoS sebelum dan sesudah pembelajaran NoS. Analisis secara kuantitatif untuk melihat perbedaan pemahaman peserta didik sebelum dan sesudah diajar dengan model pembelajaran NoS. Untuk melihat perbedaanya dilakukan uji t paired sample T test dengan menggunakan sofware SPSS versi 20.

\section{Hasil dan Pembahasan}

Hasil penelitian ini adalah nilai rata-rata pemahaman peserta didik terhadap NoS sebelum dan sesudah pembelajaran dengan model NoS. Data yang terkumpul dianalisis secara deskriptif yang mengambarkan perolehan rata-rata pemahaman peserta didik sekolah dasar terhadap NoS. Sebelum pembelajaran menggunanakan model NoS diperoleh nilai pemahaman peserta didik sekolah dasar terhadap NoS dengan nilai rata-rata 4,2 dengan persentase $84 \%$. Aspek NoS yang diukur melalui angket pemahaman NoS adalah kreatif, tentatif, subjektif, empirik, hukum dan teori, metode ilmiah, dan etos ilmiah. Pemahaman peserta didik sekolah dasar tehadap NoS sebelum diterapkan model pembelajaran NoS dapat dilihat pada gambar 2.

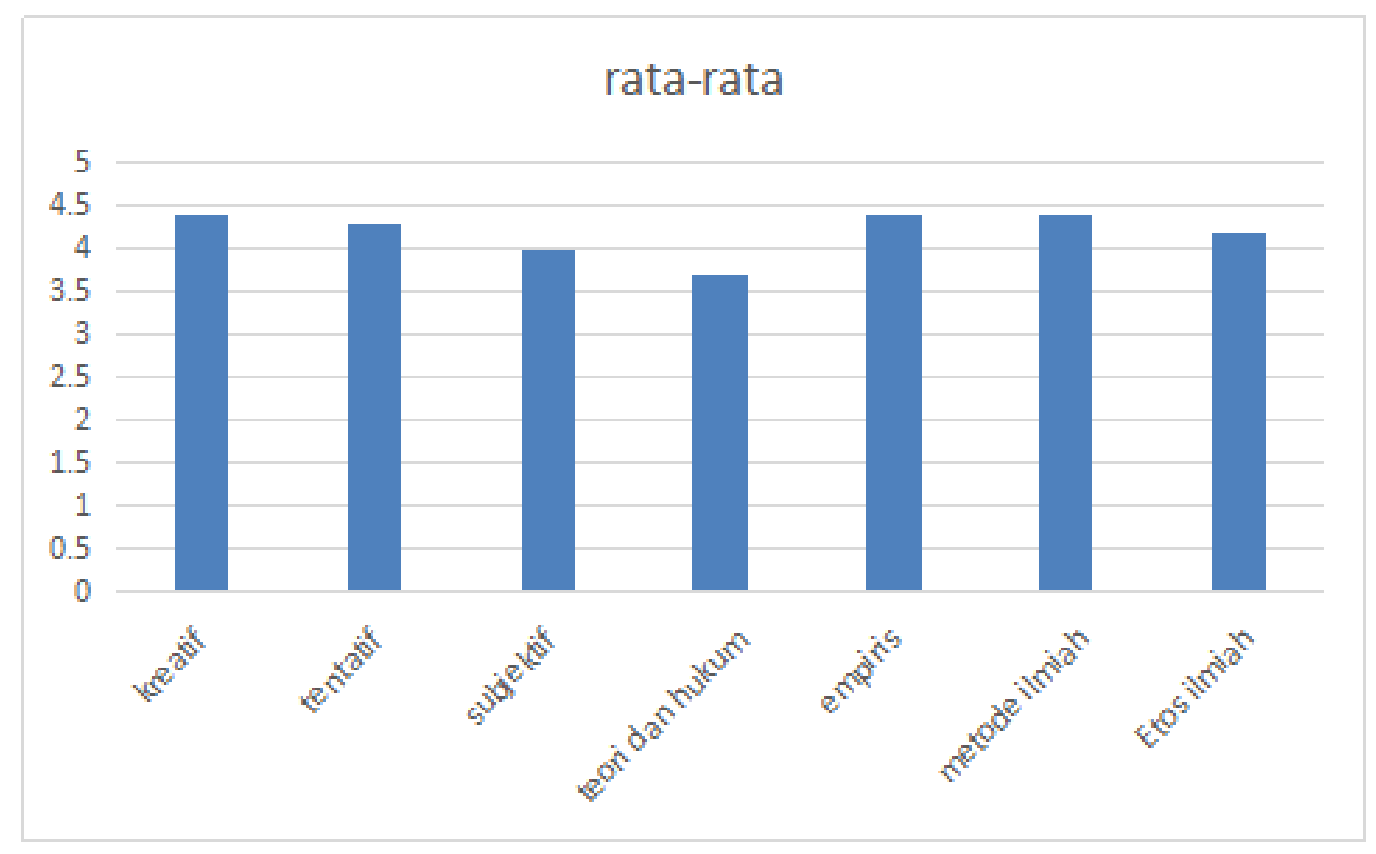

Gambar 2. Rata-rata nilai setiap aspek NoS sebelum penerapan model pembelajaran Nos

Berdasarkan gambar 2 dapat dilihat bahwa rata-rata pemahaman awal peserta didik tentang NoS sudah baik. Pemahaman awal peserta didik tentang NoS sudah baik bahwa para ilmuwan dalam melakukan penelitian dan mengembangkan pengetahuan harus kreatif, sifat ilmu itu tentatif dan dilakukan dengan langkah-langkah penelitian (metode ilmiah). Pemahaman peserta didik mengenai NoS yang terendah adalah aspek teori dan hukum, pada aspek ini siswa belum memahami aspek teori dan hukum yang biasa dipakai dalam pembelajaran. Hasil ini sama dengan yang ditemukan oleh Adi dan Widodo (2018) bahwa 
pemahaman peserta didik tentang aspek hukum dan teori masih kurang dan ditemukan juga pemahaman guru sekolah dasar bahwa aspek hukum dan teori ini yang paling rendah dibandingkan aspek lainnya. Rendahnya pemahaman peserta didik tentang hukum dan teori perlu diperhatikan lagi indikator yang terdapat dalam aspek hukum dan teori. Aspek hukum dan teori memiliki dua indikator yaitu: (1) Hukum menggambarkan hubungan, pengamatan atau persepsi, fenomena di alam. Hukum biasanya disertai dengan rumus matematis. (2) Teori adalah penjelasan yang disimpulkan untuk fenomena alam dan mekanisme hubungan antara fenomena alam.

Hasil ini berbeda dengan yang ditemukan oleh Tursinawati (2013) yang meneliti pemahaman NoS oleh siswa SD di kota Banda Aceh 40\% pada kategori tidak baik (buruk), dan 60\% pada kategori cukup. Selain itu Adi dan Widodo (2018) dan Jumanto dan Widodo (2018) bahwa pemahaman NoS peserta didik sekolah dasar yang masih dalam kategori cukup. Hal ini bisa terjadi karena lokasi sekolah yang berbeda dan jumlah sampel yang berbeda. Peneliti sebelumnya menggunakan sampel peserta didik kelas 5 dan 6 sementara dalam penelitian ini menggunakan sampel peserta didik kelas 5 .

Setelah pembelajaran menggunanakan model NoS diperoleh nilai pemahaman peserta didik sekolah dasar terhadap NoS. Pada gambar 3 ditampilkan data pemahaman peserta didik sekolah dasar tehadap NoS sesudah pembelajaran model NoS. Setelah penerapan model pembelajaran Nos diperoleh nilai pemahaman peserta didik sekolah dasar terhadap NoS dengan nilai rata-rata 4,5 dengan persentase $89 \%$ pada kategori sangat baik. Data pemahaman peserta didik sekolah dasar tehadap NoS sesudah diterapkan model pembelajaran NoS ditampilkan dalam gambar 3 .

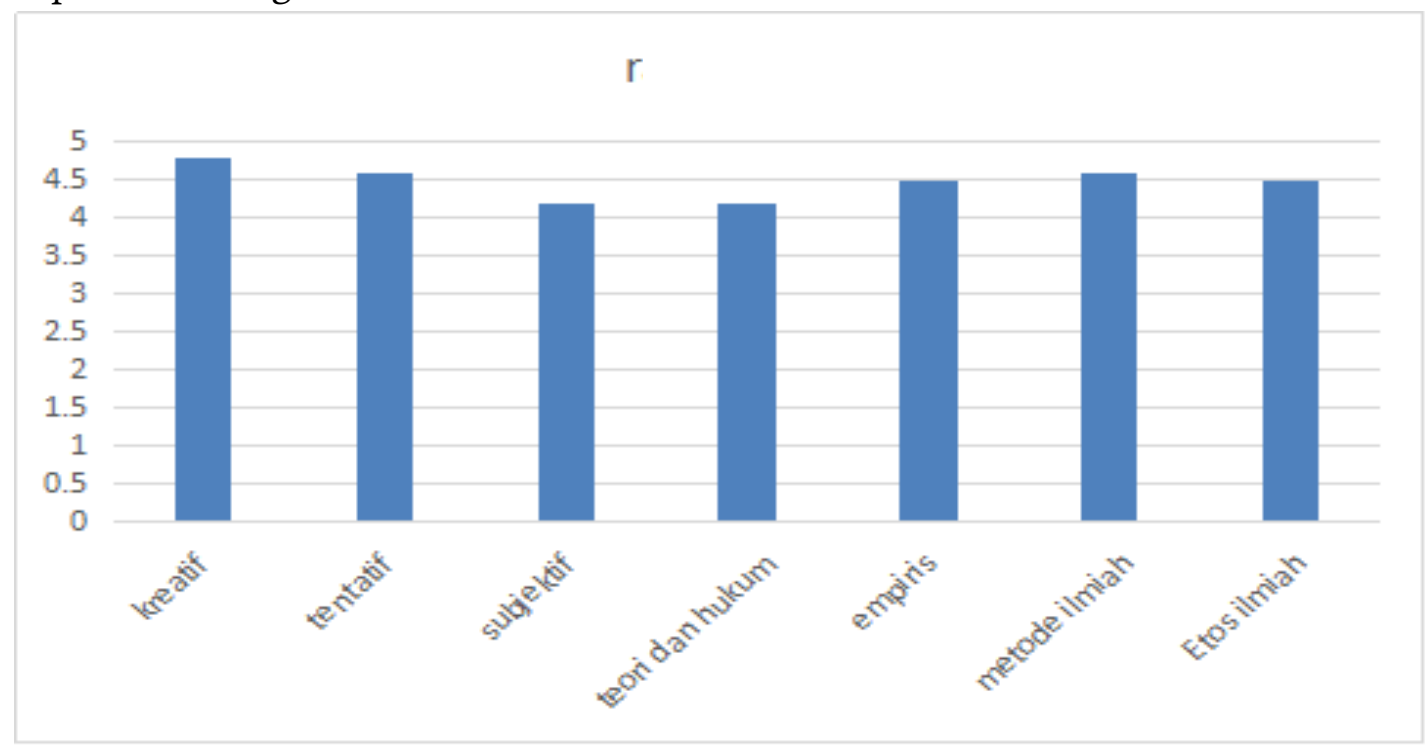

Gambar 3. Rata-rata nilai setiap aspek NoS setelah penerapan model pembelajaran NoS

Berdasarkan gambar 3 dapat dilihat pemahaman peserta didik tentang NoS sangat baik. Pemahaman peserta didik pada masing-masing aspek Nos mengalami peningkatan. Hasil angket pemahaman peserta didik tentang NoS mengalami peningkatan dari kategori baik menjadi sangat baik. Peningkatan terbesar terdapat pada aspek kreatif, hukum dan teori. Adanya peningkatan pemahaman peserta didik menunjukkan adanya peranan dari model pembelajaran Nos yang digunakan. Aspek NoS yang memiliki pemahaman yang tinggi saat tes awal dan tes akhir adalah etos ilmiah pada pernyataan bahwa "Dalam penelitian, ilmuwan harus 
jujur dengan hasil temuannya". Hal ini menunjukkan bahwa peserta didik sekolah dasar memahami bahwa jujur menjadi sifat dari seorang ilmuwan dan dalam mengembangkan pengetahuan. Temuan ini sejalan dengan yang ditemukan oleh Anggraeni dan Widodo (2019) bahwa pemahaman NoS tertinggi pada aspek etos ilmiah.

Untuk mengetahui apakah terdapat perbedaan pemahaman peserta didik sekolah dasar terhadap NoS sebelum dan sesudah pembelajaran dengan NoS dilakukan uji t dengan taraf signifikansi 5\% dengan menggunakan sofware SPSS versi 20. Hasilnya disajikan dalam tabel 2.

Tabel 2. Hasil uji t pemahaman NoS peserta didik sekolah dasar

\begin{tabular}{|c|c|c|c|}
\hline \multirow{2}{*}{} & \multicolumn{2}{|c|}{$\begin{array}{c}\text { Uji sampel } \\
\text { berpasangan }\end{array}$} & \multirow{2}{*}{ Sig. (2 ekor) } \\
\cline { 2 - 3 } & $\begin{array}{c}\text { Rata- } \\
\text { rata }\end{array}$ & $\begin{array}{c}\text { Standar } \\
\text { deviasi }\end{array}$ & \\
\hline Pretes-postes & $-0,43$ & $-0,42$ & 0,000 \\
\hline
\end{tabular}

Berdasarkan tabel 2 dapat dilihat nilai signifikansi 0,000. Nilai sig. $=0,000$ lebih kecil dari nilai $\alpha=0,05$ maka $\mathrm{H}_{1}$ diterima dan $\mathrm{H}_{0}$ ditolak.. Hal ini berarti terdapat perbedaan yang signifikan pemahaman NoS peserta didik sebelum dengan sesudah pembelajaran dengan model pembelajaran NoS.

Berdasarkan hasil perolehan nilai rata-rata dan hasil uji signifikasi terdapat pengaruh penggunaan model pembelajaran Nos terhadap pemahaman Nos peserta didik Sekolah dasar. Adapun langkah-langkah pembelajaran dalam model pembelajaran Nos yang digunakan dalam penelitian ini adalah 1) Mengaktifkan pengetahuan sebelumnya tentang bagaimana ilmuwan menggunakan metode ilmiah dalam melakukan penelitian dan mengembangkan ilmu pengetahuan, 2) Menemukan bukti secara ilmiah bahwa dalam melakukan metode ilmiah, ilmuwan harus kreatif, tentatif, empirik, hukum dan teori dan etos ilmiah, 3) Menganalisis bukti bahwa dalam bekerja dan mengembangkan pengetahuan, ilmuwan sudah sesuai dengan metode ilmiah yang dipengaruhi kreatif, tentatif, empirik, hukum dan teori dan etos ilmiah, 4) Mengkomunikasikan hasil kajiannya bahwa dalam bekerja dan mengembangkan pengetahuan, ilmuwan sudah sesuai dengan metode ilmiah yang dipengaruhi kreatif, tentatif, empirik, hukum dan teori dan etos ilmiah, 5) Menyimpulkan bahwa dalam bekerja dan mengembangkan pengetahuan, ilmuwan sudah sesuai dengan metode ilmiah yang dipengaruhi kreatif, tentatif, empirik, hukum dan teori dan etos ilmiah.

Pembelajaran dengan model NoS secara eksplisit dapat meningkatkan pemahamanan peserta didik sekolah dasar tentang bagaimana ilmuwan bekerja dan mengembangkan ilmu pengetahuan. Pada sintaks model pembelajaran NoS yang digunakan ditekankan pada aspek metode ilmiah yaitu bagaimana seorang ilmuwan melakukan langkah-langkah ilmiah beserta aspek-aspek NoS lainnya. Dalam pengajaran Nos harus dibuat secara eksplisit tidak cukup hanya implisit saja dalam suatu kegiatan pembelajaran. Hasil ini sesuai dengan yang dilakukan oleh Meichtry (1992), bahwa pendekatan implisit bukan cara yang efektif untuk meningkatkan pemahaman NoS peserta didik. Selain itu, dalam implementasi model NoS perlu diperhatikan kemampuan guru dalam memahami model NoS karena masih banyak guru yang belum memahami secara baik tentang konsep NoS.

\section{Kesimpulan}

Pemahaman NoS siswa sekolah dasar setelah menggunakan model pembelajaran NoS dalam kategori baik. Pemahaman NoS mengalami peningkatan setelah digunakan model 
pembelajaran NoS. Hasil penelitian ini yang masih rendah dibandingkan aspek NoS lainnya adalah pemahaman peserta didik tentang hukum dan teori. Berdasarkan hasil penelitian ini dapat dilakukan penelitian lanjutan yang fokus meningkatkan pemahaman tentang hukum dan teori peserta didik serta dapat juga menggunakan kelas kontrol.

\section{Daftar Pustaka}

Adi, Y. K., \& Widodo, A. (2018). Pemahaman Hakikat Sains Pada Guru Dan Siswa Sekolah Dasar. Edukasi Journal, 10(1), 55-72. https://doi.org/10.31603/edukasi.v10i1.1831

Anggraeni, P., \& Widodo, A. (2019). Pemahaman NOS di Era Revolusi Industri 4.0 pada Mahasiswa PGSD dan Guru Sekolah Dasar. ELSE (Elementary School Education Journal): Jurnal Pendidikan Dan Pembelajaran Sekolah Dasar, 3(2), 67-86. https://doi.org/10.30651/else.v3i2.3293

Bell. (2008). Bell, R. L. (2008). Best Practices in Science Education... - Google Cendekia. https://scholar.google.com/scholar?hl=id\&as_sdt=0\%2C5\&q=Bell\%2C+R.+L.+\%2820 $08 \% 29 .+$ Best + Practices + in + Science + Education + Teaching + the + Nature + of + Science $+\%$ $3 \mathrm{~A}+$ Three + Critical+Questions. + Cengage. $+\& b \operatorname{tnG}=$

Fraenkel, J. R., \& Wallen, N. E. (1993). How to Design and Evaluate Research in Education.

Holbrook, J., \& Rannikmae, M. (2009). The Meaning of Scientific Literacy. http://www.ijese.com/

Jiang, F., \& Mccomas, W. F. (2014). Analysis of Nature of Science Included in Recent Popular Writing Using Text Mining Techniques. https://doi.org/10.1007/s11191-014-9703-0

Jumanto, J., \& Widodo, A. (2018). Pemahaman Hakikat Sains Oleh Siswa Dan Guru Sd Di Kota Surakarta. Jurnal Komunikasi Pendidikan, 2(1), 20. https://doi.org/10.32585/jkp.v2i1.61

Khine, M. S. (2013). Advances in nature of science research: Concepts and methodologies. In Advances in Nature of Science Research: Concepts and Methodologies. Springer Netherlands. https://doi.org/10.1007/978-94-007-2457-0

Lawson, A. E. (1982). The nature of advanced reasoning and science instruction. Journal of Research in Science Teaching, 19(9), 743-760. https://doi.org/10.1002/tea.3660190904

Lederman, N. G., Abd-El-Khalick, F., Bell, R. L., \& Schwartz, R. S. (2002). Views of Nature of Science Questionnaire: Toward Valid and Meaningful Assessment of Learners' Conceptions of Nature of Science. Journal of Research in Science Teaching, 39(6), 497-521. https://doi.org/10.1002/tea.10034

Mccomas, W. F. (2015). The Nature of Science \& the Next Generation of Biology Education Challenges to Inclusion of NOS in the Classroom This issue of The American Biology Teacher features articles related to the nature of science ( NOS ). The American Biology Teacher, 77(7), 485-491. https://doi.org/10.1525/abt.2015.77.7.2.THE

Meichtry, Y. J. (1992). Influencing student understanding of the nature of science: Data from a case of curriculum development. Journal of Research in Science Teaching, 29(4), 389-407. https://doi.org/10.1002/tea.3660290407

Mercado, C. T., Macayana, F. B., \& Urbiztondo, L. G. (2015). Examining Education Students' Nature of Science (NOS) Views. Asia Pacific Journal of Multidisciplinary Research, 3(5), 101110. www.apjmr.com

Olson, M. \& J. (1998). The nature of science in international science education standards documents. Springer. https://link.springer.com/content/pdf/10.1007/0-306-472155_2.pdf 
Rahayu, A. H., \& Widodo, A. (2019). Understanding of Nature of Science Pre-Service Students and Elementary School Teachers in the Digital Age. Formatif: Jurnal Ilmiah Pendidikan MIPA, 9(2), 161-172. https://doi.org/10.30998/formatif.v9i2.3251

Tursinawati, T. (2013). Analisis Kemunculan Sikap Ilmiah Siswa Dalam Pelaksanaan Percobaan Pada Pembelajaran Ipa Di Sdn Kota Banda Aceh. In PIONIR: JURNAL PENDIDIKAN (Vol. 4, Issue 1). https://doi.org/10.22373/pjp.v4i1.157

Tursinawati, T., \& Widodo, A. (2019). Pemahaman Nature of Science (NoS) Di Era Digital: Perspektif Dari Mahasiswa PGSD. Jurnal IPA \& Pembelajaran IPA, 3(1), 1-9. https://doi.org/10.24815/jipi.v3i1.13294

Wallace, B. (2013). Book Review: Mind Expanding: Teaching for Thinking and Creativity in Primary Education. In Gifted Education International (Vol. 29, Issue 1). https://doi.org/10.1177/0261429412440656 